\title{
Saudi Financial Structure and Economic Growth: A Macroeconometric Approach
}

\author{
Mohammed Moosa Ageli ${ }^{1} \&$ Shatha Mousa Zaidan ${ }^{2}$ \\ ${ }^{1}$ Assistant Professor of Economics, King Saud University, Riyadh, Saudi Arabia \\ ${ }^{2}$ Lecturer of Business Administration and Finance, Princess Nora University, Riyadh, Saudi Arabia \\ Correspondence: Mohammed Moosa Ageli, Assistant Professor of Economics, King Saud University, Riyadh, \\ Saudi Arabia. E-mail: m.m.ageli@gmail.com
}

Received: December 6, 2012

Accepted: January 29, $2013 \quad$ Online Published: February 22, 2013

doi:10.5539/ijef.v5n3p30

URL: http://dx.doi.org/10.5539/ijef.v5n3p30

\begin{abstract}
This paper investigates the nexus between financial sector development and economic growth in the Saudi economy over the period 1970-2012 by using four alternative proxies for financial development and several techniques including unit root tests, the co-integration test, the Granger Causality Test, and the Vector Error Correction Model (VECM). We used time series econometrics techniques to examine the causal relationship between financial sector development and economic growth in the Saudi economy. The results obtained from the analyses show that there is a positive relationship between financial sector development and economic growth in Saudi Arabia. The development of the financial system will thus have a positive impact on the growth of the Saudi economy.
\end{abstract}

Keywords: financial sector development, unit root test, co-integration test, Vector Error Correction Model (VECM), Augmented Dickey Fuller (ADF), economic growth

\section{Introduction}

The financial sector in Saudi Arabia is one of the most important sectors and acts as a device to encourage the development process. The growth of the Saudi economy in the period of 1970-2012 was not homogeneous. According to the main economic theory of developing countries, Saudi Arabia fits into this classification.

Some research has found that financial sector development is a major sector in developing countries, as less-developed financial systems can affect the economic growth in those countries. On the other hand, other research has found that a negative relationship exists between finance and growth in developed countries (Aghion et al., 1999).

The role of financial expenditure in promoting economic growth remains a debatable subject in both developing and industrial countries. The size and role of the public and financial sectors in the Saudi Arabian economy has changed over the last thirty years since the 1980s when the public sector was the most prominent sector. This study has the following objectives:

1) To examine the effect of the stock market index and the total exports on economic growth, taking into account the positive effect of money supply and bank credit development on economic growth.

2) To apply the unit root test whether the variables are non-stationary.

3) To apply the johansen's co-integration analysis to exmamines of a long-run equilibrium relationship.

The rest of this paper is structured as follows: section two will present some historical studies; section three will derive the formulae and data; then, we will describe the methodology and results and perform the unit root tests and Johansen's co-integration test to confirm the uniqueness of the co-integration vectors among the variables under study. Using annual data for Saudi Arabia for the period 1970-2012, we will investigate the relationship between the development of the financial sector and the economic growth using appropriate estimation methods. Finally, we will use the Error Correction Model (ECM) to test the short-run relationship between financial sector development and economic growth (GDP) during the period 1970-2012. The final section will present the results and the conclusions. 


\section{Literature Review}

Previous economic studies have performed some case studies on this topic, thus this paper will review some important related studies on the issue of financial sector development and economic growth in economic history.

Kiran et al (2009) used Fully Modified OLS (FMOLS) methods for ten emerging countries and found that there is a positive relationship between financial development and economic growth using time series data over the period 1968-2007.

In the same line, Apergis et al. (2007) argued that there is a positive relationship between financial sector development and economic growth and showed this using data for " 15 countries of the Organization for Economic Co-operation and Development (OECD) and 50 non-OECD countries". In another study, Guryay et al (2007) used the Granger causality test to present their results and found a positive effect of financial development on the economic growth of Cyprus.

In another study, Neusser and Kugler (1998) analyzed the relationship between financial development and economic growth for 13 OECD countries using time series for the period 1970-1991. Time series analysis showed a positive correlation between financial development and growth.

A study by Rousseau and Wachtel (1998) in five industrialized countries found a positive and significant relationship between financial development and economic growth. Levine et al. (2000) supported the view that there is a positive correlation between financial system and economic growth using time series data for the period 1960-1995.

Sanusi and Salleh (2007) analyzed the casual relationship between financial development and economic growth in Malaysia, using time series data for the period 1960-2002. The results indicated a positive relationship between financial development and economic growth in the long run.

Fatima (2004) conducted a study in Morocco using the Granger causality test to investigate the relationship between financial development and economic growth from time series data for the period 1970-2000. The study found a positive relationship between financial development and economic growth. Ndebbio (2004) found a positive impact of growth rate in per capita real money balances on real per capita GDP growth in African countries.

Similarly, Khan et al (2005) found a positive impact on economic growth in the long run but found that the relationship was insignificant in the short run by testing the link between financial development and economic growth in Pakistan using time series data for the period 1971-2004.

Pradhan (2009) examined the causal nexus between financial development and economic growth in India using monthly data for the period 1993-2008 in the VAR model. He found no relationship between financial development and economic growth in India. He used the index of industrial production as a proxy to economic development.

\section{The Model and Data}

To test the nexus relationship between financial sector development and economic growth, we use the following model (equation 1):

$$
G D P_{t}=\alpha_{0}+\alpha_{1} S T M I_{t}+\alpha_{2} M 3_{t}+\alpha_{3} B C P S_{t}+\alpha_{4} E X_{t}+\alpha_{5} B D_{t}+\alpha_{6} C C P S_{t}+\alpha_{7} F D 2002_{t}+\alpha_{8} F D 2007_{t}+\alpha_{9} F D 2010_{t}+\varepsilon_{t}
$$

We have used Gross Domestic Product (GDP) as a proxy for economic growth, and four indicators and measures of financial sector development, namely STMI, which measures the stock market index; M3, which is money supply; BCPS, which is a measure of bank credits to the private sector from government specialized and banks; $\mathrm{EX}$, which is a measure of total exports; FD, which is a financial dummy variables; $\mathrm{BD}$, which is a measured bank deposits; and CCPS, which measures bank credits given to the private sector from commercial banks. The data used in this study consist of the following variables (table 1): 
Table 1. Variables definitions

\begin{tabular}{cl}
\hline Variable & \\
\hline The symbol (LN) & Natural Logarithm \\
GDP & Gross Domestic Product \\
STMI & Stock Market Index \\
M3 & Money Supply \\
BCPS & Bank credits to the private sector from government specialized and bank \\
EX & Total Export \\
FD & Financial dummy variables (2002) and (2007) \\
BD & Bank Deposit \\
CCPS & Bank credits to the private sector from commercial bank \\
\hline
\end{tabular}

The study will cover Saudi Arabia for the period from 1970 to 2012. The data sources are the Saudi Arabian Monetary Agency (SAMA), the IMF and the International Financial Statistical Yearbook, (IFS). The time period has started and included 1970 because it was the year when the capital market and the financial sector in Saudi Arabia actually started and it was when the powerful influence of monetary policy in the Saudi economy emerged. However, time series data in this paper is reported annually, and so we used the natural logarithm with the variables. The FD dummy variable is used for 2002, to cover the collapse of the Saudi stock market, for 2007, to cover the global financial crisis, and for 2012 to cover the Arab Spring effect on Saudi stock market.

\section{Methodology and Results}

\subsection{Unit Root Tests}

If the variables under investigation are stationary, it means that they do not have unit roots and that the series is said to be $1(0)$. If the variables under investigation are non-stationary in their level form but stationary in their first-difference form, meaning that they do have unit roots, they are said to be 1(1). To test the nexus between financial sector development and economic growth for Saudi economy; we used the Augmented Dickey Fuller (ADF) $(1979,1981)$ method to test the unit root.

$$
\Delta y_{t}=\alpha+\beta y_{t-1}+\sum_{t-i}^{k} \Delta y_{t-i}+\varepsilon_{t}
$$

Table (2) presents unit root test for Augmented Dickey-Fuller test (ADF) table. It shows that all the variables tested (LNGDP, LNISTM, LNM3, LNBCPS, LNEX, LNBD and LNCCPS) have a unit root significant level of 5\% for ADF Unit Root in their First Difference. These results are consistent with the standard theory, which assumes that most macroeconomic variables are not static, but become stationary in the first difference (Enders, 1995).

$$
\ln G D P_{t}=\alpha_{0}+\alpha_{1} \ln I S T M_{t}+\alpha_{2} \ln M 3_{t}+\alpha_{3} \ln B C P S_{t}+\alpha_{4} \ln E X_{t}+\alpha_{5} \ln B D_{t}+\alpha_{6} \ln C C P S_{t}+\alpha_{7} F D 2002_{t} \alpha_{8} F D 2007_{t}+\alpha_{9} F D 2010_{t}+\varepsilon_{t}
$$

Table 2. Augmented Dickey-Fuller for stationary unit root tests

\begin{tabular}{ccc}
\hline Variables & ADF (Level) & ADF (Differenced) \\
\hline LNGDP & -0.155641 & -2.631043 \\
LNSTMI & -0.917964 & -2.104423 \\
LNM3 & -0.480012 & -2.416632 \\
LNBCPS & -0.760121 & -3.262110 \\
LNEX & -0.762910 & -2.120712 \\
LNBD & -0.798551 & -3.338131 \\
LNCCPS & -1.720314 & -4.411701 \\
1\% C-Value & -3.6752 & -2.6486 \\
5\% C-Value & -2.9665 & -1.9535 \\
10\% C-Value & -2.6220 & -1.6221 \\
\hline
\end{tabular}


Table (2) presents the stationary tests results showing that the variables are non-stationary in levels, but become stationary with the first difference; in other words, they are integrated in order one, when their first differences 1(1) are stationary.

Table 3. Regression analysis

\begin{tabular}{cccc}
\hline Variable & Coefficient & T-Statistic & Prob. \\
\hline C & 3.401901 & 4.186696 & 0.0004 \\
LNSTMI & 0.015350 & 1.114512 & 0.0966 \\
LNM3 & 0.005619 & 1.436135 & 0.0115 \\
LNBCPS & 0.155593 & 1.167616 & 0.0749 \\
LNEX & 0.387234 & 10.05235 & 0.0000 \\
FD & 0.037867 & 1.906983 & 0.0038 \\
LNBD & 0.008719 & 1.050167 & 0.1604 \\
LNCCPS & 0.096527 & 2.153945 & 0.0420 \\
R-squared & 0.992192 & & \\
\hline
\end{tabular}

Table (3) shows that the financial sector development has a significant and positive effect on economic growth.

\subsection{Johansen Co-Integration Analysis}

Co-integration tests are used to test the relationship between economic growth and financial sector development. Granger (1981) was the first to propose a connection between non-stationary series and long-run equilibrium. The purpose of conducting co-integration is to explore whether the data exhibit a long-run relationship. Engle and Granger (1987) developed and introduced the theory of co-integration.

$$
\begin{aligned}
& x_{t}=\alpha_{0}+\sum_{i=1}^{r} \beta_{x t-i} x_{t-i}+\sum_{i=1}^{s} \beta_{y t-i} y_{t-i}+\varepsilon_{t} \\
& y_{t}=\alpha_{0}+\sum_{i=1}^{r} \beta_{y t-i} y_{t-i}+\sum_{i=1}^{s} \beta_{x t-i} x_{t-i}+\varepsilon_{t}
\end{aligned}
$$

Table 4. Johansen co-integration test

\begin{tabular}{ccccc}
\hline $\begin{array}{c}\text { Hypothesized } \\
\text { No. of CE(s) }\end{array}$ & Eigen-value & $\begin{array}{c}\text { Trace } \\
\text { Statistic }\end{array}$ & $\begin{array}{c}5 \% \\
\text { Critical Value }\end{array}$ & $\begin{array}{c}1 \% \\
\text { Critical Value }\end{array}$ \\
\hline None ** & 0.968178 & 347.9647 & 156.00 & 168.36 \\
At most 1** & 0.952413 & 247.9847 & 124.24 & 133.57 \\
At most 2** & 0.852362 & 159.6743 & 94.15 & 103.18 \\
At most 3* & 0.798038 & 104.1975 & 68.52 & 76.07 \\
At most 4* & 0.648014 & 57.80693 & 47.21 & 54.46 \\
At most 5 & 0.397198 & 37.52614 & 29.68 & 35.65 \\
At most 6 & 0.323098 & 21.84733 & 15.41 & 20.04 \\
At most 7 & 0.051413 & 7.530685 & 3.76 & 6.65 \\
\hline
\end{tabular}

Table (4) shows that there is a long-run equilibrium relationship between the variables at $5 \%$ levels. We can reject the null hypothesis of the co-integration because the Trace Statistic values are greater than the critical values at 5\% levels, which indicate there is a co-integrating equation(s) at 5\%. In other words, there is a long-run relationship among the variables, meaning there is a co-integration between the real GDP and the four proxies for financial sector development. The results indicate that there is a nexus between financial sector development and economic growth for the Saudi economy.

\subsection{Vector Error Correction Model (VECM)}

The aim of Vector Error-Correction Models is to determine whether co-integration exists between two variables; for this to be true there must be Granger causality in at least one direction, but the most valuable aspect is that co-integration does not reflect the direction of the causality between the variables.

Engle and Granger (1987) provide such a procedure, which is known as the "Error-Correction Models". It explains the long-run equilibrium state in each time period. 
This model forces the long-run behavior of the variables to meet their co-integrated relationships. The Vector Error Correction Models (VECM) are given in equations:

$$
\begin{aligned}
& \Delta x_{t}=\alpha_{1}+\beta_{1} E C T_{t-1}+\sum_{i=1}^{r} \beta_{x t-i} y_{t-i}+\sum_{i=1}^{s} \beta_{y t-i} y_{t-i}+\varepsilon_{t} \\
& \Delta y_{t}=\alpha_{1}+\beta_{1} E C T_{t-1}+\sum_{i=1}^{r} \beta_{y t-i} x_{t-i}+\sum_{i=1}^{s} \beta_{y t-i} y_{t-i}+\varepsilon_{t}
\end{aligned}
$$

Where: (ECTt-1), the error correction term lagged by one period, is equivalent to ( $\left.e t=y_{t}-a-\beta_{y t}\right)$, this represents the disequilibrium residual of the co-integration equation.

Table 5. Vector Error Correction Model (VECM)

\begin{tabular}{ccc}
\hline Independent Variable & Estimated coefficients & T-test \\
\hline LNSTMI(-1) & -15.24646 & -12.2956 \\
LNM3(-1) & -12.86076 & -11.4142 \\
LNBCPS(-1) & -5.081837 & -9.83308 \\
LNEX(-1) & -1.902907 & -12.0622 \\
LNBD(-1) & -16.59397 & -12.2698 \\
LNCCPS(-1) & -0.113395 & -0.71630 \\
\hline
\end{tabular}

Table (5) indicates that there is a long-run causality between the variables. This conclusion can be drawn because the variables are statistically significant at a level of 5\%. Thus, the model of financial sector development and economic growth is found to hold in the case of Saudi Arabia.

\section{Conclusion}

Our major aim in this paper was to investigate the relationship between financial sector development and economic growth.

We used several methods to examine the relationship between financial sector development and economic growth, including unit root tests; we have found that the outcome for each variable indicated that the series are non-stationary in levels, but stationary after the first difference (i.e., order one or 1(1)). We therefore conclude that the variables have a unit root and thus are integrated in process 1(1). Johansen's co-integration analysis was applied to examine whether the variables are co-integrated in the same order, and evidence found that this was true.

The Error Correction Model (ECM) was also used on the Saudi economic data from 1970-2012. The concept of error correction is related to co-integration because the co-integration relationship describes the long-run equilibrium. If sets of variables are co-integrated, then an error correction model exists to describe the short-run adjustments to equilibrium. Thus, the relationship between financial sector development and economic growth is found to hold in the case of Saudi Arabia.

In conclusion, there is a positive relationship between financial sector development and economic growth over the long run, and the development of the financial system will have a positive impact on the growth of the Saudi economy. The development plan must take into account how the function of each group complements the functions of the others.

\section{References}

Aghion, P., Banerjee, A., \& Piketty, T. (1999). Dualism and macroeconomic volatility. Quarterly Journal of Economics, 114(4), 1359-1397. http://dx.doi.org/10.1162/003355399556296

Apergis, N., Filippidis, I., \& Economidou, C. (2007). Financial deepening and economic growth linkages: A panel data analysis. Review of World Economics, 143, 179-198. http://dx.doi.org/10.1007/s10290-007-0102-3

Dickey, D. A., \& Fuller, W. A. (1979). Distribution of the Estimators for Autoregressive Time Series with a Unit Root. Journal of the American Statistical Association, 74, 427-431.

Dickey, D. A., \& Fuller, W. A. (1981). Likelihood Ratio Statistics for Autoregressive Time Series with a Unit Root. Econometrica, 49, 1057-1072. http://dx.doi.org/10.2307/1912517

Engle, R. F., \& Granger, C. W. J. (1987). Co-Integration and Error Correction: Representation, Estimation, and Testing. Econometrica, 55, 251-276. http://dx.doi.org/10.2307/1913236 
Fatima, A. M. (2004). Does financial development cause economic growth? An empirical investigation drawing on the Moroccan experience. Working Papers 000295, Lancaster University Management School, Economics Department.

Granger, C. W. J. (1980). Testing for Causality. Journal of Economic Dynamics and Control, 2, 329-352. http://dx.doi.org/10.1016/0165-1889(80)90069-X

Gurley, J. G., \& Shaw, E. S. (1955). Financial aspects of economic development. American Economic Review, 45, 515-538.

International Monetary Fund (IMF). (2001-2010). Government Financial Statistics Yearbook. Washington: International Monetary Fund.

Johansen, S. (1988). Statistical Analysis of Co-integration Vectors. Journal of Economic Dynamic and Control, 12, 231-254. http://dx.doi.org/10.1016/0165-1889(88)90041-3

Khan, M. A., Qayyum, A., \& Saeed, A. S. (2005). Financial development and economic growth: the case of Pakistan. The Pakistan Development Review, 44(2), 819-837.

Kiran, B., Yavus, N. C., \& Guris, B. (2009). Financial development and economic growth: A panel data analysis of emerging countries. International Research Journal of Finance and Economics, 30, 1450-2887.

Levine, R., Loayza, N., \& Beck, T. (2000). Financial intermediation and growth: Causality and causes. Journal of Monetary Economics, 46, 31-77. http://dx.doi.org/10.1016/S0304-3932(00)00017-9

Neusser, K., \& Kugler, M. (1998). Manufacturing growth and financial development: evidence from OECD countries. Review of Economics and Statistics, 80, 638-646. http://dx.doi.org/10.1162/003465398557726

Pradhan, R. (2009). The Nexus between Financial Development and Economic Growth in India: Evidence from multivariate VAR Model. International Journal of Research and Reviews in Applied Sciences, 1, 141-151.

Samudram, M., Nair, M., \& Vaithilingam, S. (2009). Keynes and Wagner on Government Expenditures and Economic Development: The Case of a Developing Economy. Empirical Economics, 36, 697-712. http://dx.doi.org/10.1007/s00181-008-0214-1

Sanusi, N. A., \& Sallah, N. H. M. (2007). Financial development and economic growth in Malaysia: An $\begin{array}{lllll}\text { application of } & \text { ARDL } & \text { approach. } & \text { Retrieved }\end{array}$ http://www.ibacnet.org/bai2007/proceedings/Papers/2007bai7443.doc

The Saudi Arabia Monetary Agency (SAMA). (2001 to 2009). Annual Report. SAMA. 